\title{
Study on aerobic granular sludge formation in sequencing batch reactors for tapioca wastewater treatment
}

- Nguyen Thi Thanh Phuong

University of Technology, VNU-HCM

- Nguyen Van Phuoc

- Thieu Cam Anh

Institute for Environment and Resources, VNU-HCM

(Manuscript Received on January 21 ${ }^{\text {st }}$, 2013, Manuscript Revised May 04 ${ }^{\text {th }}$, 2013)

\section{ABSTRACT:}

Aerobic granular sludge has attracted extensive interest of researchers since the 90 s due to the advantages of aerobic granules such as good settling ability, high biomass accumulation, being resistant to high loads and being less affected by toxic substances. Studies, however, which have mainly been carried out on synthetic wastewater, cannot fully evaluate the actual ability of aerobic granules. Study on aerobic granular sludge was performed in sequencing batch reactors, using seeding sludge taken from anaerobic sludge and tapioca wastewater as a substrates. After 11 weeks of operation, the granules reached the stable diameter of 2- $3 \mathrm{~mm}$ at 3.7 $\mathrm{kgCOD} / \mathrm{m}^{3}$. day organic loading rate. At high organic loads, in range of 1.6 - 5 $\mathrm{kgCOD} / \mathrm{m}^{3}$.day, granules could treat effectively COD, $N, P$ with performance of 93 - 97\%; 65 - 79\% and $80-95 \%$, respectively.

Keywords: Aerobic granular sludge, sequencing batch reactor, tapioca wastewater.

\section{INTRODUCTION}

Aerobic granular sludge formation and applying them in practical wastewater treatment was concerned for many years with some advantages as follows: high Stability and flexibility, Low energy requirements, Reduced footprint, Good biomass retention, Reduced investment and operational costs.

Traditionally, flocculated sludge with low settling velocities is applied and large settling tanks are needed to separate clean effluent from separate tanks are needed to accommodate the different treatment processes. Conventional processes need many steps for nitrogen, COD and phosphate removal, with large recycle flows and a high total hydraulic retention time. Surplus sludge from a municipal wastewater plant needs different steps to dewater (e.g. thickening and filterpressing) before it can be processed. To overcome the disadvantages of a conventional wastewater treatment plant, biomass has to be 
grown in a compact form, like aerobic granular sludge.

The new aerobic granular sludge technology has the ability to contribute to and improve the biological treatment of wastewater. Compared to present wastewater treatment plants, similar efficiencies at lower costs can be achieved with the compact aerobic granular sludge technology.

Granular sludge was first found in anaerobic upflow anaerobic sludge blanket (UASB) reactors to treat industrial wastewaters at the end of the 1970s (Lettinga, 1980) [9]. Anaerobic granular sludge consists mainly of methanogenic, syntrophic acetogenic and various hydrolyticalfermentative bacteria and has been widely applied in full-scale anaerobic reactors for wastewater treatment since the 1980s (Hickey, 1991) [6]. Aerobic granular sludge is developed under aerobic conditions and mainly used for the aerobic degradation of organics and also for nitrogen removal under aerobic and anoxic conditions (Liu, 2004) [11]. Aerobic granular sludge was first reported in a continuous aerobic upflow sludge blanket reactor by Mishima and Nakamura (1991) [12]. Aerobic granules with diameters of 2 to $8 \mathrm{~mm}$ were developed, with good settling properties. Aerobic granulation has since been reported in sequencing batch reactors (SBRs) bymany researchers(Morgenroth et al., 1997; Beun et al., 1999; Peng et al., 1999; Etterer and Wilderer, 2001; Tay et al., 2001a; Liu and Tay, 2002)and has been used in treating highstrength wastewaters containing organics, nitrogen and phosphorus, and toxic substances(Jiang et al., 2002; Moy et al., 2002; Tay et al., 2002e; Lin et al., 2003; Yang et al., in press). Development of biogranules requires aggregation of microorganisms. This study attempted to observe the biomass profile and reactor performances for the treatment of COD, $\mathrm{N}$ and $\mathrm{P}$ with the presence of successfully developed aerobic granular sludge.

\section{MATERIALS AND EXPERIMENTAL PROCEDURES \\ Experimental set-up}

Experiments were performed in an open, cylindrical column typed SBR with a working volume of $5 \mathrm{~L}$ shown in Figure 1. Diameter, height of this model and working height are 90 $\mathrm{mm}, 1000 \mathrm{~mm}$ and $800 \mathrm{~mm}$, respectively. Influent was fed from a storage canister at a loading rate of $1.2 \mathrm{kgCOD} / \mathrm{m}^{3}$.day. Aeration was provided by means of air bubble diffusers at a superficial air velocity of $5 \mathrm{~L} / \mathrm{min}$. The reactor was operated in successive cycles of $3 \mathrm{~h}$ comprehended a feeding period of 5 minutes, a reaction period of 170 minutes, a settling period of 2 minutes, an effluent withdrawal period of 3 minutes. Granular development stage was operated in a time sequence of 5 minute filling, 170 minute aeration, 3 minute settling and 2 minute withdrawal. The short settling time enhanced the granular development, enabled to select and retain good biomass, primarily granules which settling velocity is higher than 8 $\mathrm{m} / \mathrm{h}$.

\section{Wastewater and seed sludge preparations}

Experiments were conducted with tapioca wastewater (after anaerobic tank) taken at cassava starch-processing plants in Binh Phuoc province (table 1). A suitable amount of nutrients were supplemented to ensure a feed COD:N:P ratio of 100:5:1. Prior to feeding the $\mathrm{pH}$ of the mixed liquor was adjusted to a level of between 6.8 and 7.2 using $1 \mathrm{M} \mathrm{NaHCO} 3$ or $1 \mathrm{M} \mathrm{NaOH}$ and $1 \mathrm{M}$ HCL.

The initial seeding sludge was anaerobic sludge taken at Cassava starch processing factory in Binh Phuoc province. The initial MLSS and MLVSS concentration in the reactor were 7,273 $\mathrm{mg} / \mathrm{L}, 4,500 \mathrm{mg} / \mathrm{L}$, respectively. And the ratio between MLVSS and MLSS was $62.3 \%$. 
Table 1. Characteristics of tapioca wastewater taken at cassava starch- processing plants in Binh Phuoc

\begin{tabular}{|c|c|c|}
\hline Parameters & Unit & Values \\
\hline $\mathrm{pH}$ & - & $5.4 \pm 0.3$ \\
\hline $\mathrm{COD}$ & $\mathrm{mg} / \mathrm{L}$ & $2,842 \pm 308$ \\
\hline $\mathrm{BOD}$ & $\mathrm{mg} / \mathrm{L}$ & $1,801 \pm 103$ \\
\hline $\mathrm{SS}$ & $\mathrm{mg} / \mathrm{L}$ & $800 \pm 30$ \\
\hline $\mathrm{N}^{-N_{3}}$ & $\mathrm{mg} / \mathrm{L}$ & $19.2 \pm 3.5$ \\
\hline Total Nitrogen & $\mathrm{mg} / \mathrm{L}$ & $72.3 \pm 5.8$ \\
\hline $\mathrm{P}_{3} \mathrm{PO}_{4}^{-}$ & $\mathrm{mg} / \mathrm{L}$ & $23 \pm 5$ \\
\hline
\end{tabular}

\section{Analytical methods}

The diameter of granules was determined using a microscope model Olympus BX 51 with an attached DP 71 camera. The sludge structure and inner microbial organization were characterized by Gram staining according to Hucker and Conn methods. The microbial morphology was observed by using Olympus BX 51 microscope afterward. Parameters such as MLSS, MLVSS, COD, SVI, N-NO ${ }_{3}^{-}, \mathrm{N}_{-} \mathrm{NO}_{2}^{-}$, Total Phosphorous, and alkalinity were carried out according to Standard Methods [8].

\section{Reactor operation}

The experiment were carried out in two stages: the first stage is sludge acclimation and aggregation; the second one is granule maturation and loading increasing. The reactor was operated in batch mode, feeding and withdrawal automatically. Each cycle had four steps: influent filling, aeration, settling and effluent withdrawal.

\section{RESULTS AND DISCUSSION}

\section{Sludge acclimation and aggregation stage}

After one week of acclimation, anaerobic biogas sludge has transformed completely into aerobic sludge, shown by the color of sludge (switch from black to dark brown); MLSS increased from 3,584 mg/L to 4,932 mg/L, while the ratio of MLVSS / MLSS increased from $50.1 \%$ to $75 \%$ (Figure 2 ).

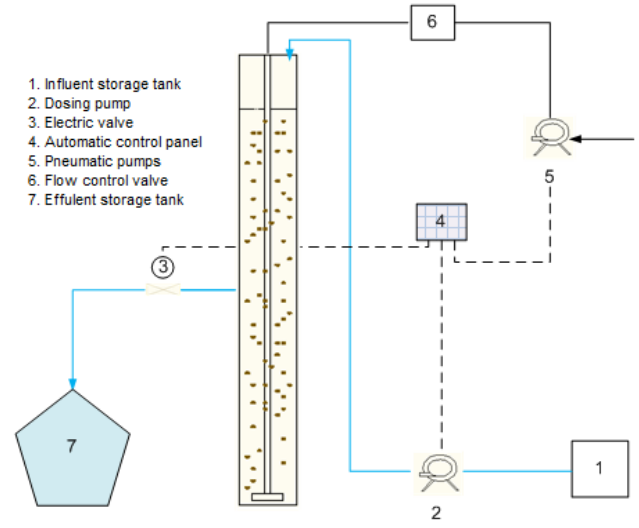

Figure 1. Experimental diagram

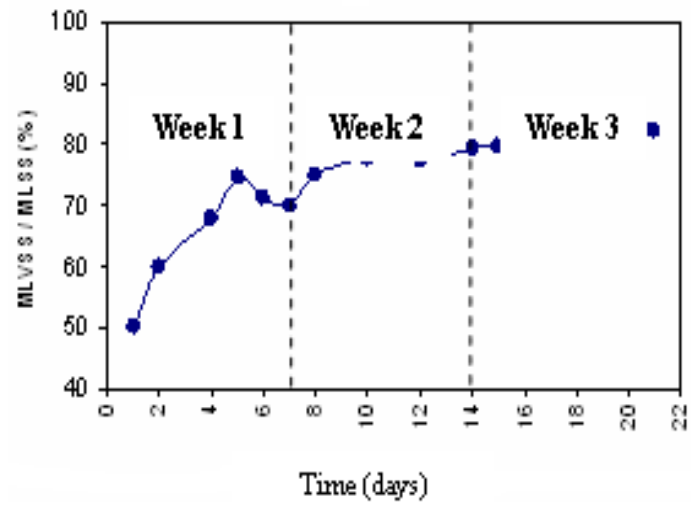

Figure 2. Change of MLVSS / MLSS ratio at the organic loading rate of $1.2 \mathrm{kgCOD} / \mathrm{m}^{3}$.day

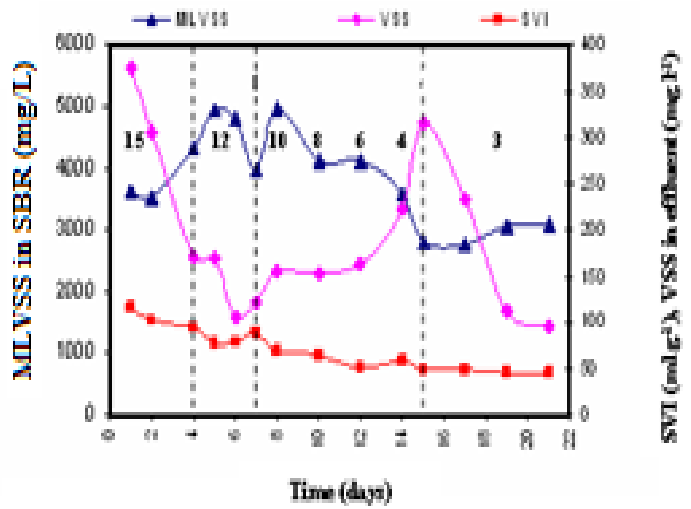

Figure 3. Change of SS, VSS in SBR corresponding to different operation time. 


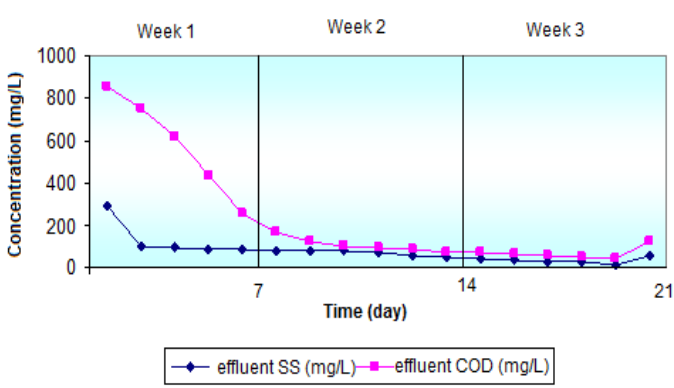

Figure 4. Change of COD at the OLR of $1.2 \mathrm{~kg}$ $\mathrm{COD} / \mathrm{m}^{3}$.day

Although biomass content reduced, COD removal efficiency still increased from $70-81 \%$ to a stable value of $91-93 \%$ at the end of the 2nd week. At the same time, the ratio of MLVSS / MLSS increased to value of $79 \%$ at the 14 th day. Protozoa appeared in sludge such as Rotifer, Cilia, and Flagella.... At the 3rd week, the settling time was maintained at the value of 3 minutes, biomass content decreased to $2754 \mathrm{mg} / \mathrm{L}$ as a result. However, COD removal efficiency was still higher than $92 \%$ (Figure 4) and the sludge volume index (SVI) was lower than 50 $\mathrm{mL} / \mathrm{g}$ due to a drop of water content in sludge and an increase in biomass density. It indicated that aerobic granules were formed, which can settle well and can treat the COD in wastewater. At the end of 3rd week, biomass content increased to $3000 \mathrm{mg} / \mathrm{L}$ because aerobic granular systems promote better biomass retention compared to initial sludge, in addition, VSS concentration of effluent was under $100 \mathrm{mg} / \mathrm{L}$ (Figure 3 and 4).

At this time, the sludge color switched from dark brown to light brown, sludge flocs had a tendency to segregate. Granular core appeared in streak shape, which had a diameter of $2 \mathrm{~mm}$ (Figure 5.e). Granules core was formed; the rate of MLVSS / MLSS also increased rapidly and reached the value over $80 \%$ at the end of the 3rd week (Figure 2).
Development of granules (from the $4^{\text {th }}$ week onwards)

After 22 days of operation (the $4^{\text {th }}$ week), granules began to appear and increase about both diameter and density afterward. The sludge in the reactor was nearly completely granulized, and visually no suspended biomass was present. Due to the intensive mixing by aeration, the granular sludge became spherical with a smooth surface. At the $6^{\text {th }}$ week, other forms of Rotifer and Cilia appeared at higher density, and Rotifer was still dominant (Figure 7.b, c). From week 7 to 9 (at the loading of $2.5 \mathrm{kgCOD} / \mathrm{m}^{3}$.day), the microorganism as Protozoa, Rotifer, Cilia, Flagella... in the granules gradually disappeared, bacteria were the majority of granules (Figure 7.d).

Aerobic granules diameter reached $2 \mathrm{~mm}$ after 6 weeks (Figure 5.d) and was stable until the $13^{\text {th }}$ week. Most of the biomass was kept in the reactor due to the good settle ability. After the granules matured point, the granules were stable and dynamically balanced in the maturation phase. In this phase, the granular size might still be shifting mainly between 2.0 and $3.0 \mathrm{~mm}$, but slowly and slightly, depending on the change of operational conditions. And the mature granules contained Filamentous in core; the next layers were bacteria (mainly Gram negative), fungi, and protozoa (Figure 7.e). At week 11, density of bacteria in sludge was higher (Figure 7.f). From week 11 , when the organic loading rate increased from 3.7 to $5 \mathrm{~kg} \mathrm{COD} / \mathrm{m}^{3}$.day, granule diameter continued to increase to $3 \mathrm{~mm}$ (Figure $5 \mathrm{f}$ ). The change of granules diameter can be shown in figure 6 . When the diameter increased, however, it was difficult for the substances to diffuse into the granules core, leaded to broken granules if the OLR was increased. As a result, the outside layer was taken out while the black core remained. Subsequently, the broken granules recovered quickly, aggregated and increased the 
biomass. The OLR was stopped at $5 \mathrm{~kg}$ $\mathrm{COD} / \mathrm{m}^{3}$.day to avoid breaking granules.

At the organic loading rate of $2.5 \mathrm{~kg}$ $\mathrm{COD} / \mathrm{m}^{3}$.day, VSS concentration increased to $6325 \mathrm{mg} / \mathrm{L}$ (at week 8), If the OLR increased to 3.7 - $5 \mathrm{kgCOD} / \mathrm{m}^{3}$.day, the value of VSS would reach as high as $7360 \mathrm{mg} / \mathrm{L}$ at the loading of 5 $\mathrm{kgCOD} / \mathrm{m}^{3}$.day (Figure 8). At OLR of 1.6 $\mathrm{kgCOD} / \mathrm{m}^{3}$.day, SVI changed continuously in the range of $38.4-39.6 \mathrm{~mL} / \mathrm{g}$. As OLR increased to $2.5 \mathrm{kgCOD} / \mathrm{m}^{3}$.day, granules were formed developed stably leads to SVI decreased from $38.4 \mathrm{~mL} / \mathrm{g}$ at $6^{\text {th }}$ week to $26 \mathrm{~mL} / \mathrm{g}$ at $9^{\text {th }}$ week. When increasing the OLR up to 3.7 $\mathrm{kgCOD} / \mathrm{m}^{3}$.day, granular sludge developed more stably, tightly and heavily. It can be proved through SVI, SVI decreased from the $26 \mathrm{~mL} / \mathrm{g}$ at $9^{\text {th }}$ week to $22.6 \mathrm{~mL} / \mathrm{g}$ at $11^{\text {th }}$ week.

When OLR increased to $5 \mathrm{kgCOD} / \mathrm{m}^{3}$.day, more sludge can be formed and granules were grown, as a result, SVI increased rapidly up to $64.69 \mathrm{~mL} / \mathrm{g}$ at $12^{\text {th }}$ week and $65.61 \mathrm{~mL} / \mathrm{g}$ at $13^{\text {th }}$ week. Research results about SVI variation with different OLR were matched with the studies of Bui Xuan Thanh, Nguyen Phuoc Dan [21]. The change of SVI at different loading was presented in Fig 9.

In this study, the removal performances of $\mathrm{COD}, \mathrm{NH}_{4}^{+}, \mathrm{NO}_{2}^{-}, \mathrm{NO}_{3}^{-}$, and total phosphorous were investigated. The results were shown in Figure 10, 12, 13, 14. The following would explain the removal performance. At the beginning, COD removal efficiency was $91.2 \%$. When increasing OLR to $1.6 \mathrm{kgCOD} / \mathrm{m}^{3}$.day, 2.5 $\mathrm{kgCOD} / \mathrm{m}^{3}$.day, $3.7 \mathrm{kgCOD} / \mathrm{m}^{3}$.day, and 5 $\mathrm{kgCOD} / \mathrm{m}^{3}$.day COD removal efficiency was $93.2 \%, 95.6 \%, 94.8$, and $95.1 \%$, respectively. The COD removal efficiency was optimal at the organic loading rate of $2.5 \mathrm{kgCOD} / \mathrm{m}^{3}$.day (Figure 10). It reached the value of $95.6 \%$ while MLVSS/MLSS ratio was over $90 \%$. Moreover,
MLVSS/MLSS ratio was always over $80 \%$ at all OLRs (Figure 11). These values were higher than using conventional activated sludge, which MLVSS/MLSS ratio was about 65 - 75\% (Figure 11). The result also indicated that the biomass density was quite high in granule structure.

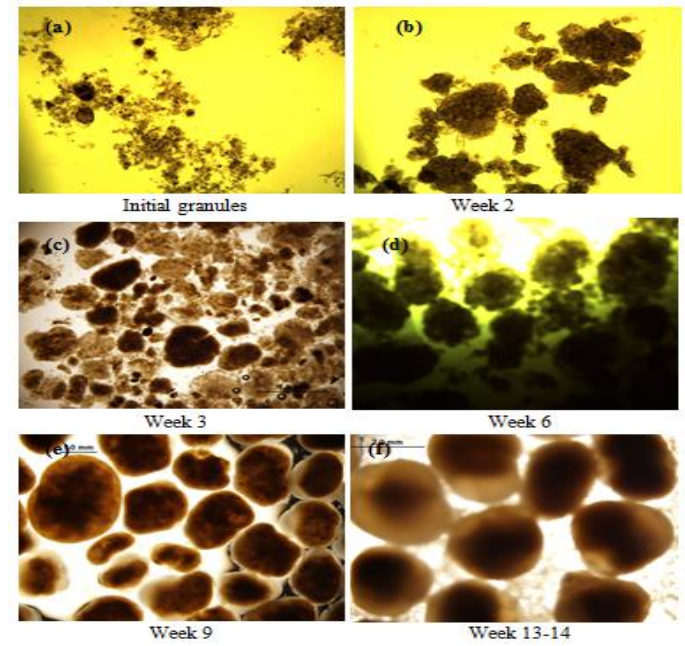

Figure 5. Granules in different weeks (a. initial granules; b. granule aggregation; c. forming granules; d. growing granules; e. stable granules; f. granular core)
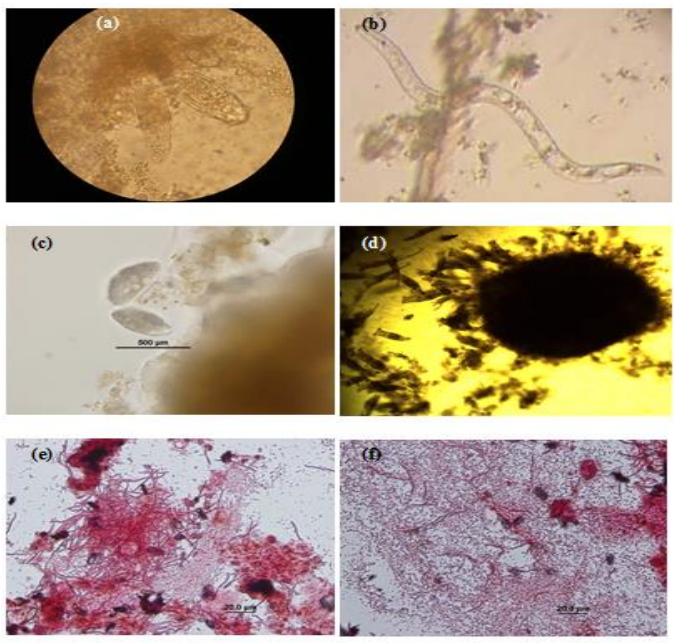

Figure 7. Microorganism in the granules (a. Rotife; b. Red Nematode; c. Cilia; d. protozoa around the granules; e. granule structure; f. bacilli and cocci bacteria) 

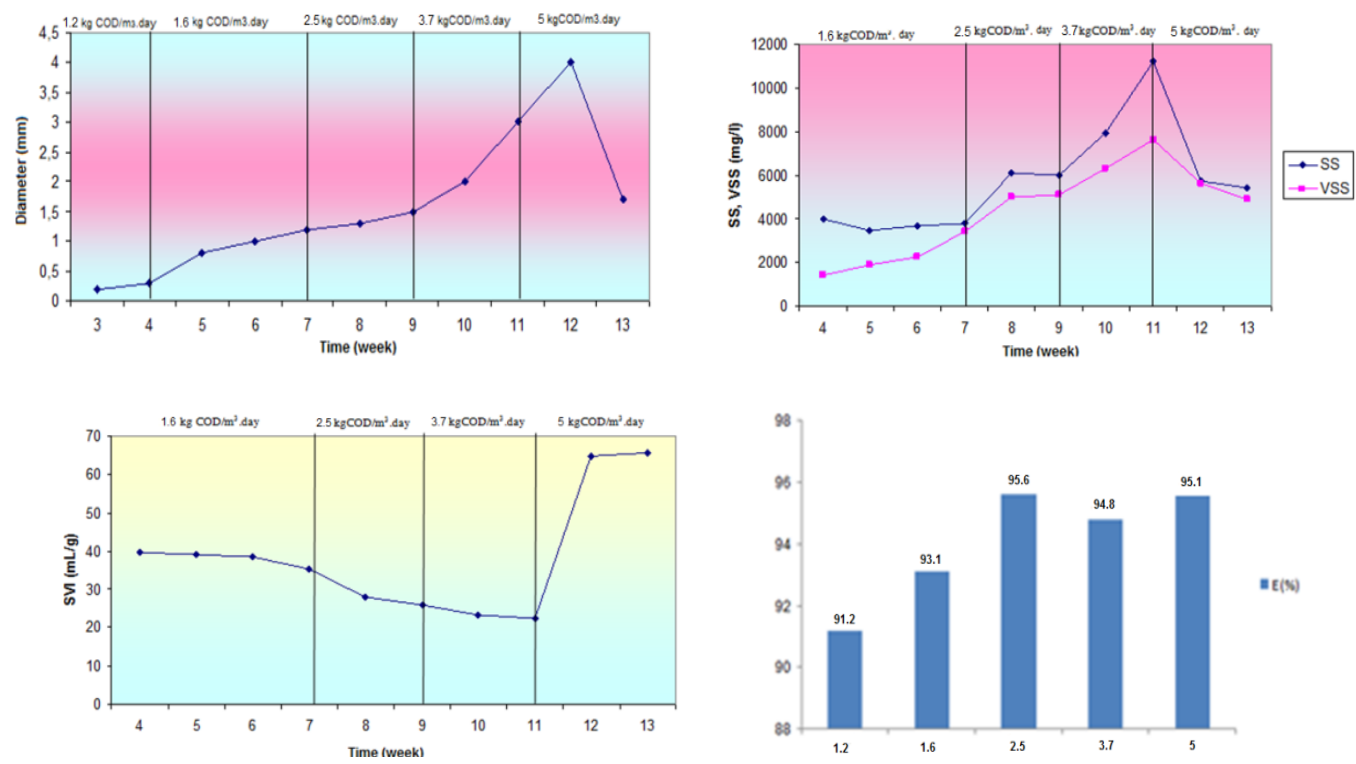

Figure 9. The variation of SVI at different organic loading rates

Figure 10. COD removal efficiency at different organic loading rates
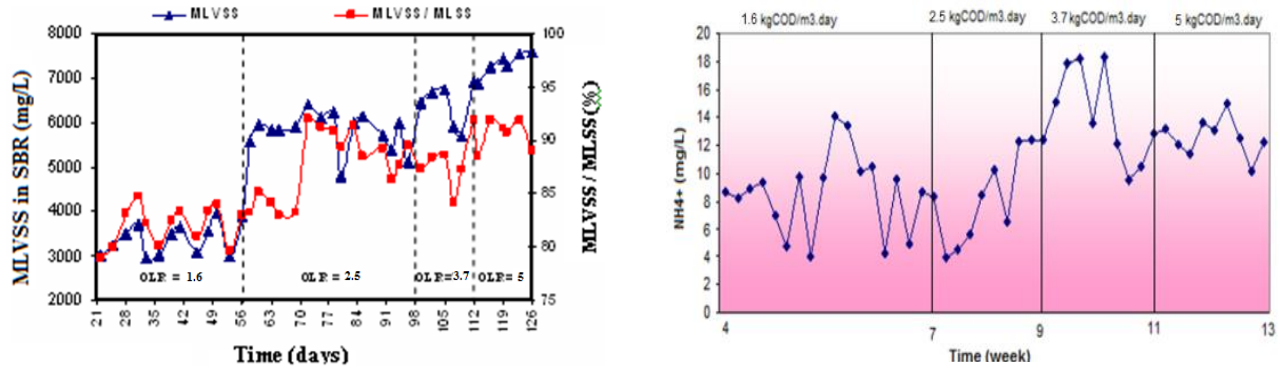

Figure 11. The variation of MLVSS and MLVSS / MLSS ratio at different organic loading rates

Figure 12. Change of $\mathrm{NH}_{4}^{+}$concentration at different organic loading rates
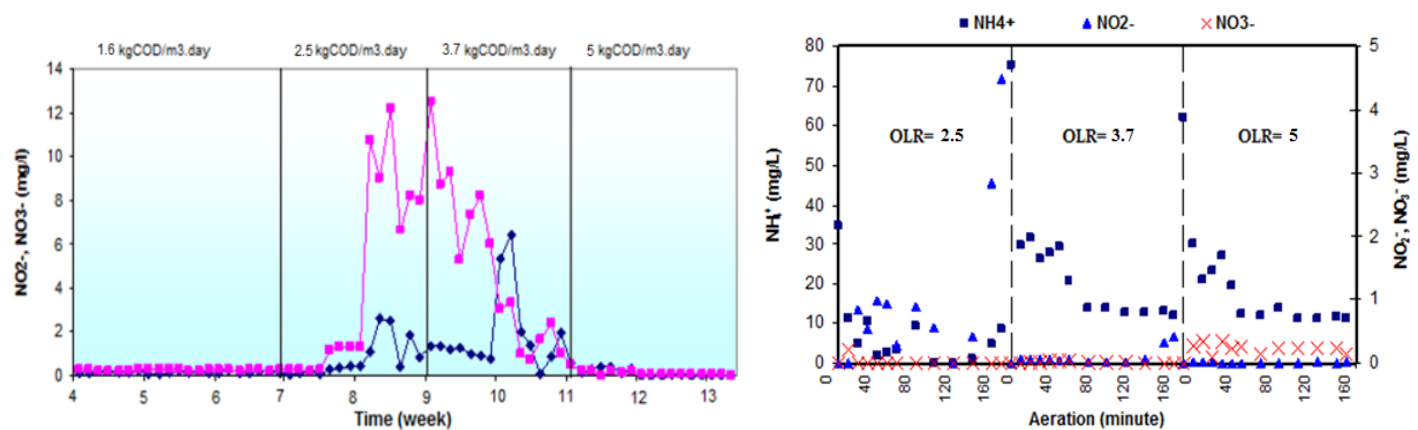

Figure 13. Change of $\mathrm{NO}_{2}{ }^{-}, \mathrm{NO}_{3}{ }^{-}$concentration at different organic loading rates

Figure 14. Variation of $\mathrm{N}$ concentration at different organic loading rates 


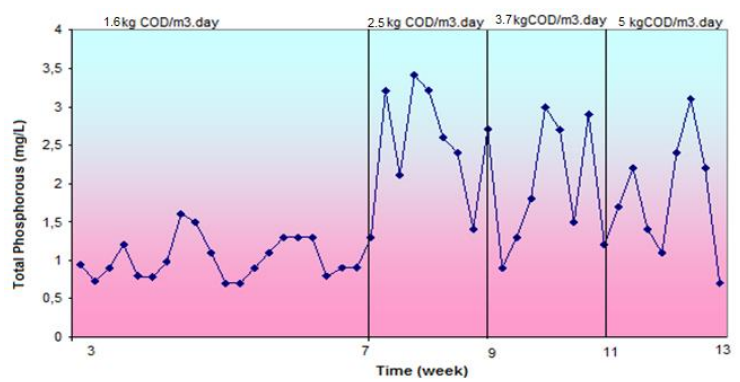

Figure 15. Change of total phophorus concentration at different organic loading rates

Phosphorous removal efficiency was presented in Figure 15. Concentration of influent phosphorous increased with increasing OLR corresponding to COD. At OLR of 2.5 $\mathrm{kgCOD} / \mathrm{m}^{3}$.day corresponding to input $\mathrm{P}$ about $11 \mathrm{mg} / \mathrm{L}$, effluent $\mathrm{P}$ fell to less than $1.6 \mathrm{mg} / \mathrm{L}$, effective treatment was about $80.0-95.2 \%$. At higher loading of $3.7-5 \mathrm{kgCOD} / \mathrm{m}^{3}$.day corresponding influent $\mathrm{P}$ in water were 18 and $23 \mathrm{mg} / \mathrm{L}$, respectively, effluent $\mathrm{P}$ was always less than $4 \mathrm{mg} / \mathrm{L}$. Effective treatment was in range of 80.7-96.0\% (Figure 15). The above results indicated that $\mathrm{P}$ treatment in the model have been rather stable. $\mathrm{P}$ was removed by the synthesis of the bacterial cytoplasm. P was consumed rapidly in the first minute of the aeration process. The higher OLR was operated corresponding to the higher $\mathrm{P}$ concentration, the longer time consumed the $\mathrm{P}$ content. At OLR of $2.5 \mathrm{kgCOD} / \mathrm{m}^{3}$.day, $\mathrm{P}$ was removed within 10 minutes of aeration process, while at OLR of 3.7; $5 \mathrm{kgCOD} / \mathrm{m}^{3}$.day, the time to treat $\mathrm{P}$ content up to 30 minutes. In the remaining time of the aeration process, $\mathrm{P}$ concentration in the reaction tank was changed in a range of $0.1 \mathrm{mg} / \mathrm{L}$ to $1 \mathrm{mg} / \mathrm{L}$ due to decomposition and synthesis of bacterial cell in reaction tank when the substrate was depleted.

\section{CONCLUSION}

Aerobic sludge particles can be formed from the initial culture anaerobic sludge without carriers and with the short time for granulation formation (only in 3 adaption weeks). When the organic loading rate increased, the particle size of granules also increased and gained a stable size of $2-3 \mathrm{~mm}$ at OLR of $3.7-5 \mathrm{kgCOD} / \mathrm{m}^{3}$.day. After 6 weeks of operation, the granules were formed and grown with a range of $0.5-1.2 \mathrm{~mm}$. Aerobic granules were in a good settling ability with SVI in the range of $22.6-64.6 \mathrm{~mL} / \mathrm{g}$, much higher than conventional activated sludge with SVI > $100 \mathrm{~mL} / \mathrm{g}$ [22] leads to decrease the settling time to 3 minutes. Due to the accumulation of high level of biomass, granules can remove efficiently organic matter at high organic loading rate. At OLR of 5 $\mathrm{kgCOD} / \mathrm{m}^{3}$.day, with $\mathrm{F} / \mathrm{M}=0.79-1.63$ (L/day), COD, nitrogen and phosphorus removal efficiency can reach 92-98\%, 60-68\% and 80$96 \%$, respectively. The study opens a new possibility for making granules and applications of aerobic granules for high organic matter and nutrients pollution wastewater treatment in practice. 


\section{Nghiên cứu tạo bùn hạt hiếu khí trên mô hình SBR để xử lý nước thải chế biến tinh bột khoai mì}

- $\quad$ Nguyễn Thị Thanh Phượng

Trường Đại học Bách Khoa, ĐHQG-HCM

- Nguyễn Văn Phước

- Thiệu Cẩm Anh

Viện Môi trường và Tài nguyên, ĐHQG-HCM

\section{TÓM TÁ́T:}

Bùn hạt hiếu khí đã được rất nhiều nhà nghiên cứu quan tâm từ những năm của thập niên 90 do những ưu điểm của bùn hạt hiếu khí mang lại như khả năng lắng tốt, tích lũy sinh khối cao, chịu được tải trọng cao và it bị ảnh hưởng bởi các chất độc hại. Tuy nhiên, các nghiên cứu chủ yếu được tiến hành trên nước thải tổng hợp nên chưa đánh giá được đầy đủ khả năng xử lý thực tế của bùn hạt hiếu khí. Đề tài nghiên cứu tạo bùn hạt hiếu khí trên nước thải thực tế là nước thải tinh bột mì và qua đó đánh giá hiệu quả xử lý chất hữu cơ của bùn hạt hiếu khí. Trong nghiên cứu này, bùn hạt hiếu khí được nuôi cấy trên mô hình bể phản ứng từng mẻ (SBR) từ bùn nuôi cấy ban đầu là bùn kị khí. Sau 11 tuần nuôi cấy, bùn hạt kích thước ổn định từ 2 - $3 \mathrm{~mm}$ ở tải trọng 3.7 $\mathrm{kgCOD} / \mathrm{m}^{3} . n g a ̀ y$. Với tải trọng hữu co cao, dao động từ 1.6 - $5 \mathrm{kgCOD} / \mathrm{m}^{3}$.ngày, bùn hạt xử lý hiệu quả $C O D, N, P$ với hiệu suất xử lý tương úng đạt $93-97 \%$; $65-79 \%$ và $80-$ $95 \%$.

Từ khóa: bùn hạt hiếu khí, SBR, nước thải tinh bột mì.

\section{REFERENCES}

[1]. Beun JJ, Hendriks A, van Loosdrecht MCM, Morgenroth E, Wilderer PA, Heijnen JJ. Aerobic granulation in a sequencing batch reactor. Water Res 1999;33:2283-90.

[2]. De Kreuk, M. K. (2006). Aerobic Granular Sludge - Scaling-up a new technology. Thesis, Department of Biotechnology, Technical University Delft, The Netherlands. 199p.

[3]. De Bruin, L.M.M., De Kreuk M.K., van der
[4]. Roest H.F.R., Van Loosdrecht M.C.M. and Uijterlinde C. (2004). Aerobic Granular Sludge Technology, Alternative for Activated Sludge Technology. Wat. Sci. Technol.49(11-12), 1-9.

[5]. De Kreuk, M.K. and De Bruin L.M.M. (2004). Aerobic Granule Reactor Technology. London, IWA Publishing.

[6]. Etterer T, Wilderer PA. Generation and properties of aerobic granular sludge. Water Sci Technol 2001;43:19-26. 
[7]. Hickey R.F., Wu W.M., Veiga M.C., Jones $\mathrm{R}$.

[8]. The start-up, operation and monitoring of high-rate anaerobic treatment systems. Water Sci Technol 24 (1991) 207-255.

[9]. Jiang HL, Tay JH, Tay STL. Aggregation of immobilized activated sludge cells into aerobically grown microbial granules for the aerobic biodegradation of phenol. Lett Appl Microbiol 2002;35:439-45.

[10]. Lin YM, Liu Y, Tay JH. Development and characteristics of phosphorousaccumulating granules in sequencing batch reactor. Appl Microbiol Biotechnol 2003;62:430-5.

[11]. Lettinga G., van Velsen AFM, Hosma S.W., de Zeeuw W., Klapwijk A. Use of the upflow sludge blanket (USB) reactor concept for biological wastewater treatment, especially for anaerobic treatment. Biotechnol Bioeng 22 (1980) 699-734.

[12]. Liu Y, Tay JH. The essential role of hydrodynamic shear force in the formation of biofilm and granular sludge. Water Res 2002;36:1653-65 (24).

[13]. Liu Y., Tay J.H. State of the art of biogranulation technology for wastewater treatment. Biotechnol Adv 22 (2004) 533563.

[14]. Mishima K.,Nakamura M. Selfimmobilization of aerobic activated sludge - a pilot study of the process in municipal sewage treatment. Water Sci Technol 23 (1991) 981-990.

[15]. Morgenroth E, Sherden T. Aerobic granular
[16]. Sludge in a sequencing batch reactor. Water

[17]. Res 31 (1997) 3191-3194.

[18]. Moy BYP, Tay JH, Toh SK, Liu Y, Tay STL. High organic loading influences the physical characteristics of aerobic sludge granules. Lett Appl Microbiol 2002;34:407-12

[19]. Peng D.C., Benret N., Delgenes J.P., Moletta R. Aerobic granular sludge - A case report. Water Res 33 (1999) 890-893.

[20]. Tay JH, Liu QS, Liu Y. Microscopic observation of aerobic granulation in sequential aerobic sludge blanket reactor. J Appl Microbiol 2001a;91:168-75.

[21]. Tay JH, Liu QS, Liu Y. The effects of shear force on the formation, structure and metabolism of aerobic granules. Appl Microbiol Biotechnol 2001b; 57:227-33.

[22]. Tay JH, Liu QS, Liu Y. The role of cellular polysaccharides in the formation and stability of aerobic granules. Lett Appl Microbiol 2001c; 33:222-6

[23]. Yang SF, Tay JH, Liu Y. Effect of substrate N/COD ratio on the formation of aerobic granules. J Environ Eng 2003a [in press].

[24]. APHA. Standard Methods for the Examination of Water and Wastewater. American Public Health Association, Washington, DC (2005).

[25]. Bui Xuan Thanh, Nguyen Phuoc Dan. Application of aerobic Granule for Nitrogen removal of fishery wastewater.

[26]. Metcalf and Eddy. Wastewater Engineering (1991). 